\title{
IDENTIFICATION AND SEQUENCE ANALYSIS OF A DREB SUBFAMILY TRANSCRIPTION FACTOR INVOLVED IN DROUGHT STRESS TOLERANCE FROM RICE
}

\author{
XUAN HOI PHAM, TUAN TU TRAN \\ The Institute of Agricultural Genetics, Hanoi
}

\begin{abstract}
DRE (dehydration responsive element)/CRT (C-repeat) is a cis-acting element that involves in gene expression responsive to abiotic stress in higher plants. To date, all well known DREBP transcription factors in Arabidopsis, rice, maize and other plants regulate gene expression in response to drought, high-salt and cold stresses by binding specifically to DRE/CRT. Using a target sequence of 50 nucleotides on Glutamate dehydrogenase-like protein (JRC2606) promoter containing the core sequence of DRE cis-acting element ( $\underline{\mathrm{A} / \mathrm{GCCGAC}})$ for yeast one-hybrid screening, we have identified two transcription factors: a completely homology of $O S R A P 2.4 A$ gene and another is a new sequence. The new sequence contained an ORF (Open Reading Frame) of 1017-bp and 5' non-coding area of 35-bp and 3' non-coding area of 341-bp. The deduced amino acid sequence contains an AP2 domain and belongs to the subgroup A6 of DREB subfamily, temporarily named OSRAP2.4B. Sequence alignment showed that $O s R a p 2.4 B$ had homology with $Z m D B F$, a maize transcription factor involved in drought stress tolerance.
\end{abstract}

Keywords: Transcription factor, DRE/CTR, OsRap2.4B, drought stress tolerance.

Plants are not mobile and thus must respond and adapt to abiotic stress such as drought, high salt, heat, cold in order to survive. Under these stresses, plants induce various biochemical and physiological changes in process of acquiring stress tolerance. Discovering of numerous genes responsible for stress tolerance suggests that many of them are transcription factors [16]. Among these transcription factors is an ERFBP/AP2 family has been identified in a variety of higher plants. Significantly, the introduction of many stress-inducible genes via gene transfer resulted in improved plant stress tolerance [16, 17, 19]. In Arabidopsis, this family consists of 145 distinct genes encoding ERFBP/AP2 protein and can be divided into three subgroups based on the number of ERFBP/AP2 domains in each molecule. The AP2 subgroup includes 14 genes, each encodes a protein containing two ERFBP/AP2 domains. The RAV subgroup includes six genes that conserve two different DNA-binding domains, ERFBP/AP2 and B3. The ERFBP subgroup includes 125 genes, each encodes a protein with only one ERFBP/AP2 domain. Of these, 121 genes contain a conserve WLG motif in the middle of their ERFBP/AP2 domain [15]. The 74 members of the ERFBP subgroup can be further divided into two subfamilies: DREB subfamily and DREB-like protein subfamily, based on the similarity of the amino acid sequence of the DNA-binding domain. DREB subfamily consists of 56 genes in Arabidopsis genome and all of them contain one ERFBP/AP2 domain considered to play a crucial role in the process of the response to environmental stresses. DREB subfamily is divided into 6 small groups based on similarities of the binding domain. The first and second small groups (A1, A2) include of DREB1/CBF and DREB2 gene families, respectively. The third small group (A3) has only ABI4. The fourth small group (A4) contains 16 genes, including TINY. The fifth small group (A5) consists of 16 genes, including RAP2.1, RAP2.9 and RAP2.10. The sixth small group (A6) consists of nine genes, including RAP2.4 [15].

DREB subfamily specifically recognizes and binds to the dehydration responsive element (DRE) or DRE-like cis-element. The core sequence of the DRE is A/GCCGAC that exists frequently in promoters of plant genes induced by dehydration, high salt, heat and cold stresses [18]. Both DRE-like cis-elements, named C- 
repeat (CRT) and low-temperature-responsive element (LTRE) contained a CCGAC core motif also reported to regulate low-temperature inducible promoters $[1,9]$.

DREB subfamily so far includes DREB1AC (CBF1-3), DREB2A-B, three novel DREB1s and six novel DREB2-related genes in Arabidopsis genome have been isolated, and their corresponding gene products showed significant sequence similarity to the conserved DNA-binding domain found in ERFBP/AP2 proteins $[8,11,15]$. Expression of the DREB1/CBF genes induced by cold stress and their gene products activate the expression of more than 40 genes in the DREB1/CBF region and resulted in an improved tolerance not only to freezing but also to drought and high salinity [3]. DREB1/CBF orthologs have been reported and shown to functional in cold stress tolerance from various species, including Brassica napus, tomato, barley, maize, rice, and wheat [2, 4-7, 13]. In contrast, expression of the DREB2 genes induced by dehydration or high salt stress rather than cold stress. Overexpression of $D R E B 2 A$ in transgenic plants does not activate downstream genes under normal growth condition suggesting that post-translational regulation may be involved in its activation [11]. Recently, a negative regulatory domain identified in central region of DREB2A and deletion of this region transforms $D R E B 2 A$ to a constitutive active form, DREB2ACA. Transgenic Arabidopsis overexpression $D R E B 2 A C A$ showed increased expression of many stress inducible genes and resulted in an improved tolerance to drought stress [14]. A number of efforts have been focused on characterization of drought and high-salt stress transcription factors in different plants including rice, wheat, barley and maize $[2,13]$. However, function of these genes under drought condition is not much clear, except $Z m D R E B 2 A$ that is accumulated by cold, dehydration, salinity and heat stresses. Unlike DREB2A, ZmDREB2A produced two forms of transcripts but only functional transcription form of $\mathrm{ZmDREB} 2 \mathrm{~A}$ significantly induced by stresses suggesting that protein modification is not necessary for ZmDREB2A function. Transgenic plants overexpressing $Z m D R E B 2 A$ resulted in up regulation expression of a number of drought inducible genes including late embryogenesis abundant (LEA), heat shock and detoxification proteins. Constitutive or stress-inducible expression of $Z m D R E B 2 A$ resulted in an improved drought stress tolerance in plant [13].

\section{MATERIALS AND METHODS}

\section{Plant materials and stress treatments}

An Indica rice variety namely cultivar Moc tuyen was grown in controlled conditions in incubator at $30 \pm 1^{\circ} \mathrm{C}$ and $12 \mathrm{~h}$ photoperiod. The seeds were first soaked in water at room temperature overnight and surface sterilized by bovastin powder for $15 \mathrm{~min}$ and after that kept under following water for half an hour. To germinate, seeds kept on autoclaved germination paper (at a distance app. $1 \mathrm{~cm}$ between seeds), rolled and kept into beaker. Half strength MS basal medium (liquid) supplied after seeds germinated. After ten days, drought treatments given by putting them into $20 \%$ PEG solution for $1,4,8$ and $24 \mathrm{~h}$; all of them were collected separately put in liquid nitrogen and stored at $80^{\circ} \mathrm{C}$ till the further use.

\section{Construction of stress cDNA library}

Total RNA extracted from 15-day-old rice using GITC buffer standard protocol. The mRNA was purified from total RNA by magnetic separation after annealing with biotinylated oligo-dT primer and immobilizing it onto streptavidin-linked paramagnetic beads.

cDNA Library was constructed from $5 \mu \mathrm{g}$ of mRNA in Hybrid Zap 2.1 vector by following manufacturer's (Stratagene) protocol using HybriZAP-cDNA library Synthesis Kit (HybriZAPd-2.1 XR Library construction kit and HybriZAPd-2.1 XR cDNA synthesis kit, http://www.stratagene.com/manuals/235612.pdf).

The resulting cDNA was unidirectional subcloned into EcoRI and XhoI sites within the MCS region in the phage vector, and packaged by Gigapack III Gold packaging extract. After amplification primary library according manufacturer's protocol, phage library were aliquot into eppendorf tubes and stored at $-80^{\circ} \mathrm{C}$ for long time. The titer of the cDNA library is estimate around $10^{10} \mathrm{pfu} / \mathrm{ml}$ after amplifying (data not show). After that, pAD-GAL4 2.1 
vector was excised from the Hybrid Zap 2.1 vector according to mass in vivo excision protocol from Stratagene (data not shown).

\section{Construction of reporter plasmids for yeast one-hybrid screening}

We have selected target sequences contain DRE sequences from a promoter sequence of a cold stress-inducible gene encoding glutamate dehydrogenase-like protein (JRC2606). Specific target sequence is AGCCAAACGCAGCCG GCCGACCTCCTCCCGTGCCTTCCTCCTCGA $T C C C C$. The pHISi-1 and pLacZi vectors are employed for constructing target-reporter constructs.

\section{Yeast one-hybrid screening of rice drought cDNA library}

Dual reporters of pHISi-1 and pLacZi containing four tandem copies of target sequences were linearized by $\mathrm{XhoI}$ and $\mathrm{NcoI}$ respectively, then transformed into Yeast genome (YM4271, Clontech) to form parental yeast containing both reporters. Yeast onehybrid screening of rice drought cDNA library was carried out as manual protocol of yeast one hybrid screening (Clontech). These clones were isolate with yeast DNA isolation protocol of Clontech. pAD-GAL4 plasmids containing cDNA inserts were isolated from the positive clones. After that cDNA were excised with EcoRI from pAD-GAL4 plasmid and then ligated into pSK II vector for sequencing.

\section{RESULTS}

1. Isolation of cDNA encoding DNA binding proteins that interact with DRE in the 50bp DNA fragment of JRC2606 promoter

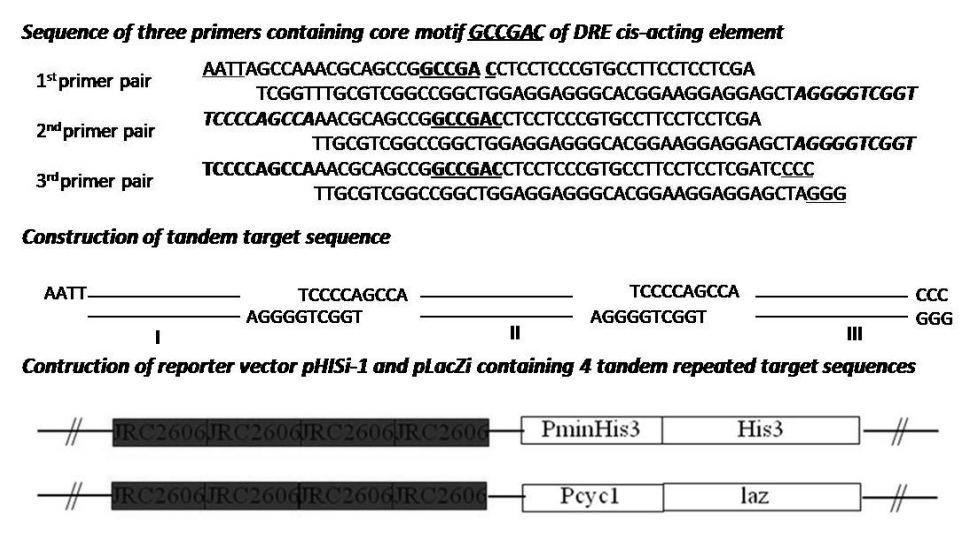

A

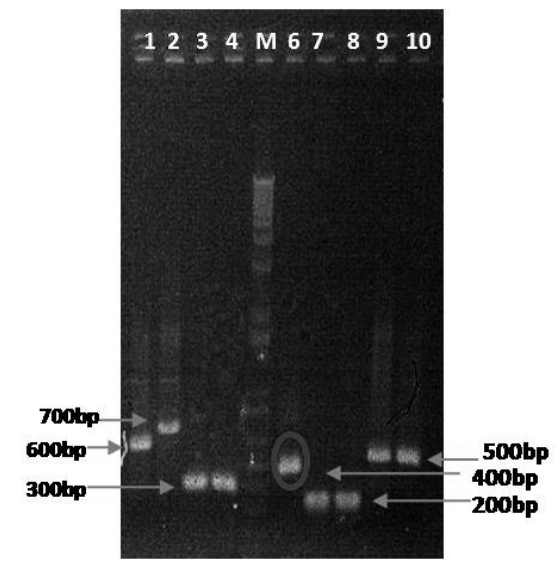

B

Figure 1. Design and construction of target sequence

Electrophoresis PCR produce with specific primer T7/T3 show that lane 7 and 8 are emty vector; lane 3 and 4 are vector containing a insert DNA including 2 tandem repeated target sequences. Similarry lane 6, lane 9/10 are the PCR produce of a vector containing 4 and 6 tandem repeated target sequence, respectively. The clone sixth was chosen for isolating plasmids and sequencing. The result also comfirm that this clone containing a vector with 4 tandem repeated target sequence be beatwen Sma I and EcoR I sitr in the MCS region.

To isolate cDNA encoding DNA binding proteins that interact with DRE motif, we have used yeast one-hybrid screening system. The first, we synthesized three pair of antiparallel oligo-nucleotides of the target sequence. In each pair, one strand represents the sense and the other its antisense complement. The sense strand of first pair of antiparallel oligonucleotides containing EcoRI site in 5' end anneals with its antisense to form fragment 1 .
The second pair of antiparallel oligo-nucleotides containing 10 nucleotides tails in both 3 ' ends forms fragment 2 , since it can be self-ligated to extend copy number. The sense strand of the third pair of antiparallel oligo-nucleotides containing SmaI site in 3' end anneals with its antisense containing SmaI site at 5' end to form fragment 3 (fig. 1A). In principle, fragments 1 , 2 and fragments 3 have 10 nucleotides overlap, therefore fragments 1,2 and 3 can anneal to 
form a sequence containing at least three tandem repeat target sequences by T4 ligase (Fig. 1a). Then the ligated DNA was cloned in pSKII vector by EcoRI/SmaI sites. The sequences cloned in pSKII vector has checked by electrophoresis on agarose gel $1 \%$ (fig. 1B) and rechecked again on sequencer ABI (3100). After that, the sequence was excised and cloned into vectors pHISi-1 and pLacZi, by EcoRI/SmaI sites (fig. 1A). The number copies of target sequences in reporter vectors pHISi-1 and pLacZi were re-confirmed by sequencing and then transformed into yeast genome. Following this strategy, we obtained a parental yeast strain containing as dual reporter genes integrated copies of HIS and LacZ with fourtime tandem repeated 50-bp DNA fragments of JRC2606 promoter. The resulting parental yeast strain transcribes the HIS3 gene at basal levels, grows on media lacking histidine and forms the blue colonies on the filter paper containing $\mathrm{X}$ gal.

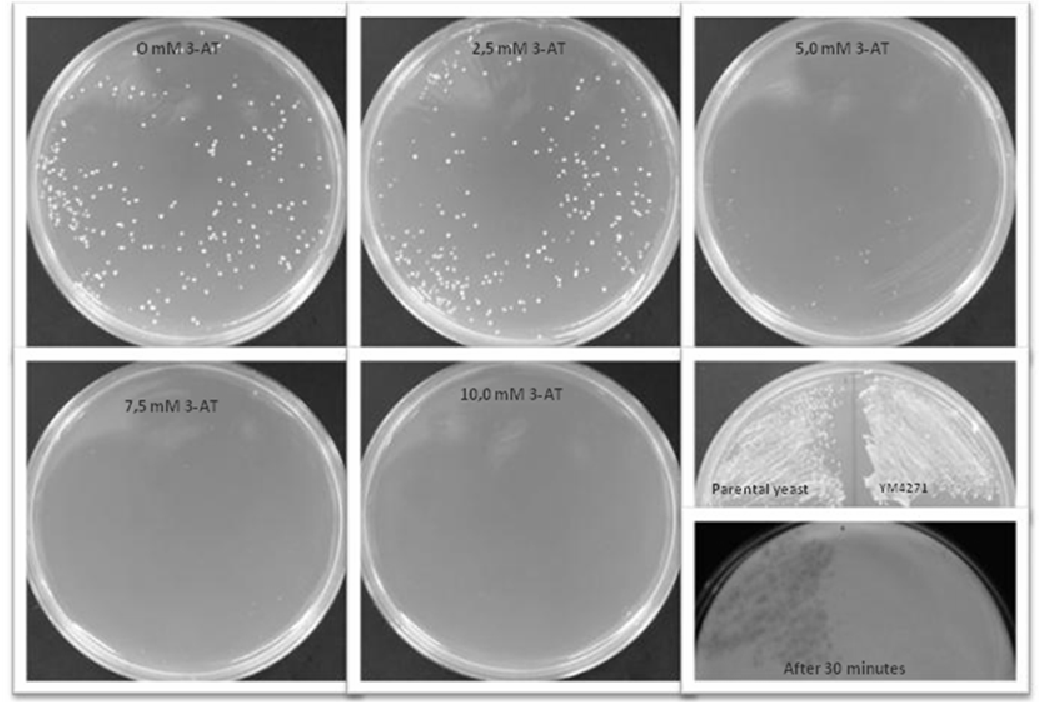

Figure 2. The basal expression level of HIS3 and LacZ genes of parental Yeast on the medium SD/-His/-Ura

The second, we discovered the basal expression level of HIS3 and LacZ genes of parental Yeast by growing the yeast strain on $\mathrm{SD} /$-His/-Ura plates containing different concentration of 3-aminotriazole (3-AT, an inhibitor of the HIS3 gene product) and $\beta$ glactosidase filter assay respectively. For basal expression level of HIS3 gene, we found that parental yeast till grew weakly on SD/-His/-Ura plates containing $7.5 \mathrm{mM} 3$-AT but did not grow on SD/-His/-Ura plates containing $10 \mathrm{mM}$ 3-AT (fig. 2). For basal expression level of $\mathrm{LacZ}$ gene, we found that filter turned blue in IPTG and X-gal media after 30 minutes (fig. 2).

The parental yeast cells transformed with drought cDNA library from a mix of rice plants dehydrated for $1,4,8$ and 24 hours. If target gene encoding transcription factor that can recognize the binding site (DRE) and like a transcriptional activator of the reporter genes it allows the recombinant yeast cells to grow in the presence of $10 \mathrm{mM} \mathrm{3-AT}$ and filter in $\beta$ glactosidase assay turned blue before 30 minutes.

Screening of $1.5 \times 10^{6}$ recombinant yeast cells, we have obtained 28 positive clones that grown on SD/-His/-Ura/-Leu containing $10 \mathrm{mM}$ 3 -AT and filter in $\beta$-glactosidase assay turned blue before 20 minutes. Re-screening 28 positive clones on $\mathrm{SD}$ /-His/-Ura/-Leu containing $50 \mathrm{mM} 3-\mathrm{AT}, 12$ positive clones have grown normally on this medium. The cDNA of these 12 chosen clones were isolated from yeast cells and subjected for sequencing.

2. Sequence and structural analysis of an DREB subfamily, OsRap2.4B 
To identify these positive clones, 12 positive clones were sequenced by $\mathrm{ABI}$ sequencer version 3100. The sequencing data revealed that, five positive clones completely match in sequence with each other's, four positive clones completely match with other sequence and remained positive clones are not match in sequence. The aligment DNA of sequences with rice genome showed that the group of five positive clones is OsRap2.4A (sequence is not shown), the other group of four positive clones is a new sequence temporary named OsRap2.4B (fig. 3). The OsRap2.4B cDNA contained an ORF (Open Reading Frame) of 1017-bp and 5' non-coding area of 35-bp and 3 ' non-coding area of 341-bp. Its deduced 339 amino acid sequence indicated that this protein with predicted molecular mass of $38 \mathrm{kDa}$ contains an AP2 domain of 59 amino acids and a WLG motif localized in central of AP2 domain (fig. 3).

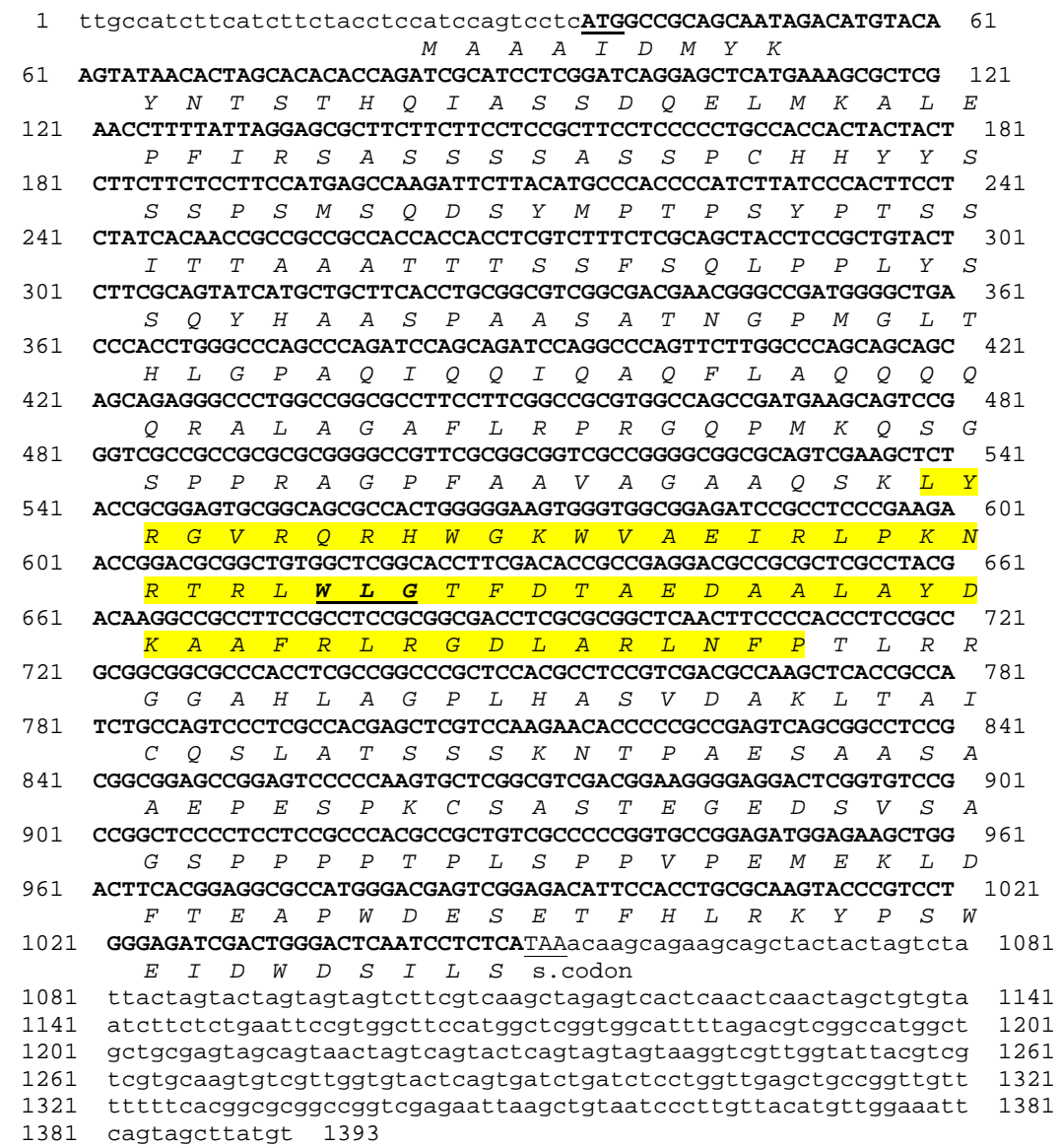

Figure 3. Nucleotide and deduded amino acid sequence of cDNA temporary named OsRap2.4B

In order to clarify the relationship of OsRap $2.4 B$ in the super family of ERF/AP2 transcription factor in plants. A systematic phylogenic analysis of the ERF/AP2 domains of these proteins was based on the classification of 121 ERF/AP2 transcription factors in Arabidopsis [15]. We have analyzed the similarities of OsRap $2.4 B$ with protein from other species including Arabidopsis, rice and revealed that it belongs to A-6 subgroup of DREB subfamily (fig. 4).
In addition, sequence alignment of OsRap 2.4B and homolog DREB subfamily transcription factors from different species shown that OsRap2.4B had striking homology with Rap2.4, OsRap2.4A and ZmDBF1 respectively. In detail, OsRap2.4B has maximum of $76 \%$ identity with Rap2.4, 67\% with OsRap $2.4 A$ and $51 \%$ with $Z m D B F 1$. There is not much homology on over the entire length of the amino acid sequence between these 
proteins. However, a striking homology on a region of 59 amino acids (AP2 domain) and WLG motif localization in central of AP2 domain were observed among these proteins. Beside, before the AP2 domain, two conserved sequences (QA/SQ, Q/LP/LMKPP/QA/S) like motif presented and after the AP2 domain, there are another two basic regions in C-terminal region. These sequences might act as an activation domain for transcription (fig. 5).

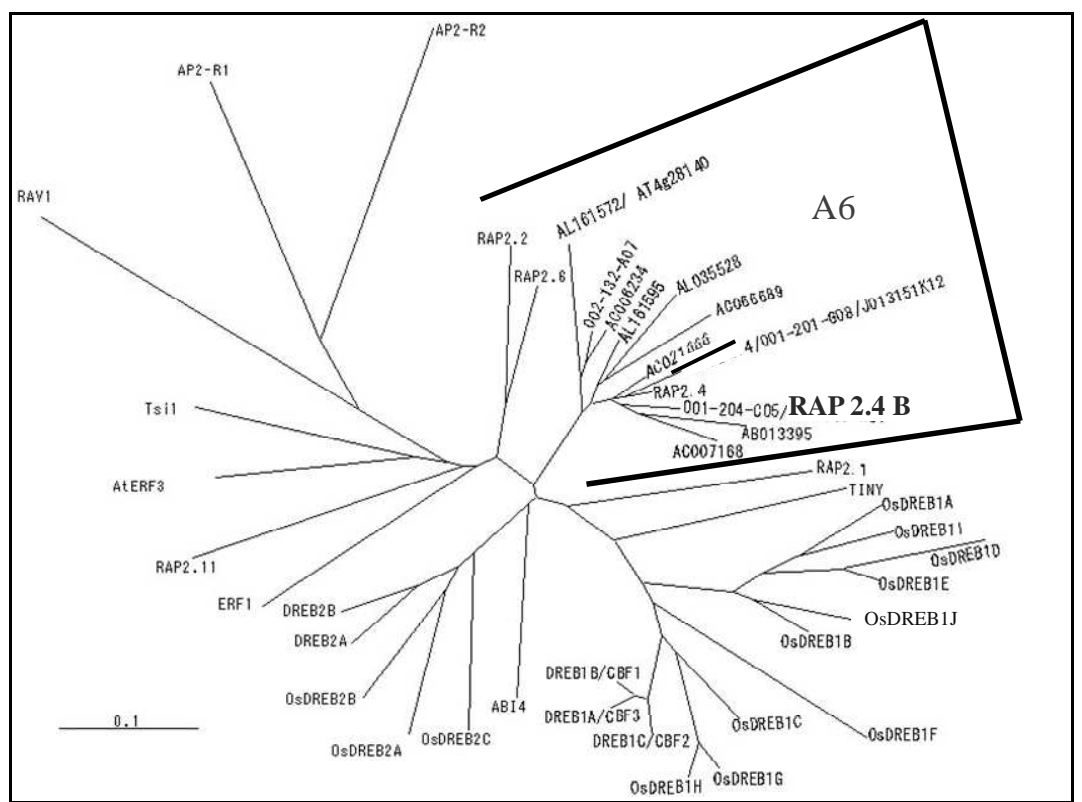

Figure 4. Phylogenic tree of OsRap2.4B built by Cluster

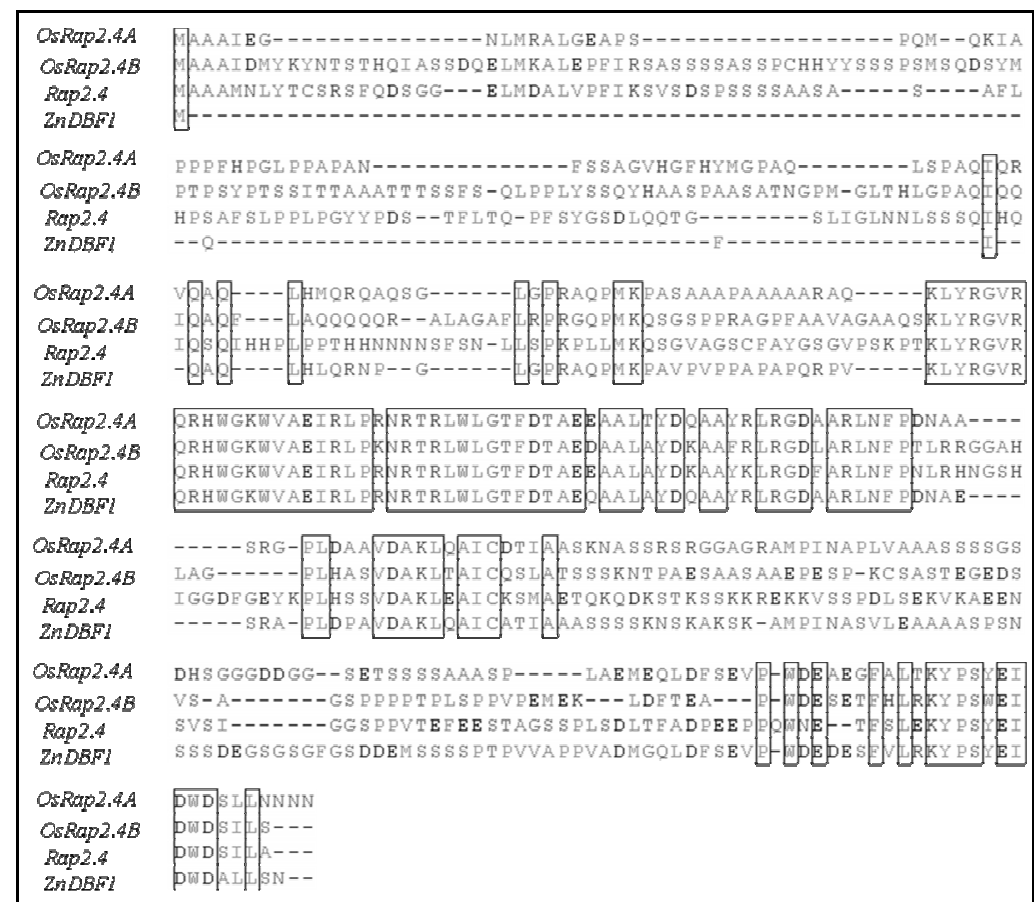

Figure 5. Alignment deduced amino acid sequences of OsRap2.4B with other similarly homology genes in A6 subgroup of DREB subfamily by Genetyx 6.0. The result show that OsRap2.4B have a strictly homology with the rest in AP2 domain and the present of WLG 


\section{DISCUSSION}

DREBP subfamily bind to DRE or DRE like cis-element and regulate expression of stress inducible genes has been accurately determined at molecular level. However, all of these studies were focused on DREB1 and DREB2 and homolog genes [16, 19], except $Z m D B F s ~[10]$. We have identified a new transcription factor, OsRap $2.4 B$ that belongs to A6 subgroup. The deduced amino acid sequence of OsRap $2.4 B$ contained an AP2 DNA binding domain of 59 amino acids and WLC motif localization in central of AP2 domain, which were conserved in all the other DREB subfamily transcription factors [15]. DRE - binding activity as well as functions of transcription factors belong to A6 subgroup has not been determined at molecular level yet.

However, at least five DREBP subfamily transcription factors: DREB1,2, OsDREB1, $Z m D R E B 1$ and $Z m D B F 1$ have been isolated by yeast one-hybrid screening and all of them contained DRE-binding activity [10-13]. Yeast one hybrid screening using a target sequence of 50 nucleotides containing DRE sequence suggesting that the new sequence identified OsRap2.4B did binding to DRE sequence. Two new DRE-binding proteins, DBF1 and DBF2 are members of the AP2/EREBP transcription factor family that bound to the wild-type DRE2 element and regulated expression of stress inducible genes and resulted in an improve drought tolerance in transgenic plants [10]. Sequence alignment of OsRap $2.4 B$ and homolog DREB subfamily transcription factors from different species showed OsRap2.4B striking homology with Rap2.4, OsRap2.4A and ZmDBF1, indicating this transcription factor may also have functions in common with $\mathrm{ZmDBF} 1$ and improve drought tolerance in transgenic plants. A futher study on function analysis of OsRap 2.4 will come out soon.

\section{REFERENCES}

1. Baker S. S., 1994: Plant Mol. Biol., 24: 701-713.
2. Dubouzet J. G. et al., 2003: Plant Journal, 33: 751-763.

3. Fowler S. and Thomashow M. F., 2002: Plant cell, 14: 1675-1680.

4. Gao M. J., Allard G., Byass L., Flanagan A. M. and Singh J., 2002: Plant Mol. Biol., 49: 459-471.

5. Hsieh T. H. et al., 2002: Plant Physiol., 129: 1086-1094.

6. Ito Y. et al., 2006: Plant Cell Physiol., 47(1): 141-153.

7. Jaglo K. R. et al., 2001: Plant Physiol., 127: 910-917.

8. Jaglo-Ottosen K. R. et al., 1998: Science, 280: 104-106.

9. Jiang C., Lu B. and Singh J., 1996: Plant Mol. Biol., 30: 679-684

10. Kizis D. and Pages M., 2002: Plant Journal, 30(6): 679-689.

11. Liu Q. et al., 1998: Plant Cell, 10: 13911406.

12. Ping L., Feng C., Chao Q. and Guiyou Z., 2005: Tsichua Science and Technology, 10(4): 478-483.

13. Qin F. et al., 2004: Plant Cell Physiol., 45: 1042-1052.

14. Sakuma Y. et al., 2006: The Plant Cell, 18: 1292-1309.

15. Sakuma Y. et al., 2002: BBRC, 290: 9981009.

16. Shinozaki K. and Yamaguchi-Shinozaki K., 2007: J. Exp. Bot., 58(2): 221-227.

17. Umezawa T. et al., 2006: Current Opinion in Biotechnology, 17: 113-122.

18. Yamaguchi-Shinozaki K. and Shinozaki K., 1994: Plant Cell, 6: 251-264.

19. Zhang J. Z., Creelman R. A., Zhu J. K., 2004: Plant physiol., 135: 615- 621. 


\title{
PHÂN LẬP VÀ PHÂN TÍCH TRÌNH TỰ GIEN MÃ HÓA NHÂN TỐ PHIÊN MÃ THUỘC PHÂN NHÓM DREB Ở LÚA LIÊN QUAN ĐẾN TÍNH CHỊU HẠN
}

\author{
PHAM XUÂN HÔI, TRẦN TUẤN TÚ
}

\begin{abstract}
TÓM TÁT
DRE (yếu tố/đoạn $\mathrm{C}$ lặp lại đáp ứng hạn) là trật tự $\mathrm{ADN}$ đặc hiệu trên vùng điều khiển hoạt động gien liên quan đến biểu hiện các gien đáp ứng với các điều kiện bất lợi ngoại cảnh ở thực vật. Tất cả các yếu tố phiên mã được nghiên cứu chi tiết đặc tính ở cây mo hình Arabidopsis, lúa, ngô và các thực vật khác điều khiển biểu hiện các gien đáp ứng với điều kiện hạn, mặn và lạnh thông qua việc bám đặc hiệu vào trình tự DRE/CRT. Sử dụng trật tự $\mathrm{ADN}$ đích gồm 50 nucleotit trên vùng điều khiển hoạt động gien Glutamate dehydrogenase-like protein (JRC2606) chứa trình tự $\mathrm{ADN}$ đặc hiệu DRE cho việc sàng lọc (yeast one hybrid screening), chúng tôi phân lập được hai nhân tố phiêm mã thuộc tiểu nhóm A6 của phân nhóm DREB và đặt tên là $O s D R E B 2.4 A$ và $O s D R E 2.4 B$. Trật tự cDNA của $O s D R E B 2.4 B$ có vùng mã hoá là $1017-b p$, vùng không mã hóa gen đầu 5 ' là 35 -bp và vùng không mã hóa gien đầu 3 là 341 cặp bazơ. Phân tích trình tự amino acid của gien $O s D R E B 2.4 B$ cho thấy có chứa vùng hoạt động $\mathrm{AP} 2$. So sánh sư tương đồng về trình tự amino acid được mã hoá bởi gien OsDREB2,4B với các nhân tố phiên mã thuộc phân nhóm DREB của các đối tượng cây trồng khác nhau cho thấy gien $O s D R E B 2.4 B$ tương đồng với nhân tố phiên mã $Z m D B F$ ở ngô. Nhân tố phiên mã $Z m D B F$ ở ngô tăng cường tính chịu hạn ở thực vật vì vậy nhân tố phiên mã $O s D R E 2.4 B$ chúng tôi mới phân lập được có thể tăng cường tính chịu hạn ở thực vật.
\end{abstract}

Ngày nhận bài: 12-11-2008 